\title{
Modeling and simulation of solar PV module for comparison of two MPPT algorithms (P\&O \& INC) in MATLAB/Simulink
}

\author{
Hayder Moayad Abd Alhussain, Naseer Yasin \\ Electrical Power Engineering Techniques, Department of Electrical Engineering Technical College \\ Middle Technical University Baghdad, Iraq
}

\begin{tabular}{l} 
Article Info \\
\hline Article history: \\
Received Aug 2, 2019 \\
Revised Nov 4, 2019 \\
Accepted Nov 18, 2019 \\
\hline Keywords: \\
DC-DC boost converter \\
Incremental conductance(INC) \\
Maximum power point tracking \\
(MPPT) \\
Perturb and observe (P\&O) \\
Photovoltaic (PV) \\
\hline
\end{tabular}

\begin{abstract}
This paper introduces a procedure for the modeling of a Photovoltaic (PV) cell and the application of "maximum power point tracking (MPPT)"in stepby-step with MATLAB/Simulink. The model of one diode is used to explore the characteristics of I-V and P-V curves of 60W PV module. Due to the non-linear and time-varying of PV characteristics, the generated power of the PV is continually varying with atmospheric conditions like temperature and irradiation, the MPPT technology is very important to chase"maximum power point (MPP)"on the P-V curve to obtain maximum output power from PV array. This study focuses on two common types of algorithms of MPPT,"namely perturb and observe (P\&O) and incremental conductance (INC)". A DC-DC boost converter is implemented to regulate the voltage output from the PV array's and for the application of the MPPT algorithm.
\end{abstract}

Copyright ()$_{2020}$ Institute of Advanced Engineering and Science. All rights reserved.

\section{Corresponding Author:}

Hayder Moayad Abd Alhussain,

Electrical Power Engineering Techniques, Department of Electrical Engineering Technical College,

Middle Technical University Baghdad, Iraq.

Email: hayder_moayad@yahoo.com

\section{INTRODUCTION}

The Photovoltaic power could be considered among the renewable energy resources as the most essential resource with the greatest development potential, so it attracts human attention because of it is ubiquitous, cost reduction, clean energy, continuity and reliability, and there is plenty of solar radiant free energy. Researchers have the best understanding of PV working principles because of the continuous updating of the mathematical modeling of solar PV cells [1]. However, the variation of the PV power generation with different atmosphere circumstances is the main challenge for the PV system applications and it is the main case that must be taken into account. Therefore, it is important to increase the efficiency of the PV system, which must operate at its maximum power point, so the maximum power point tracking MPPT is a process that responsible for obtaining the information about the highest PV power usage in the design of the console [2].

The solar cell's efficiency depends on many factors such as irradiance, temperature, shadow, dirt, spectral characteristics of sunlight, etc. The changing in insolation on PV panels due to rapid climatic changes such as an increase in ambient temperature and cloudy weather can reduce the PV panels output power. In another word, each photovoltaic cell produces energy related to its operational and environmental conditions [3]. The maximum power of the PV module generates at a single operating point. On the other hand, the operating point of the PV system can be controlled by adjusting the output power or voltage of the PV system. The output voltage and power of the PV system can be controlled by a power electronic converter which is the most common method, which in turn is controlled by a specific control algorithm to drive this procedure [4].

Therefore, most environmental factors such as ambient temperature and solar radiation greatly determine the amount of energy that can be produced. So, an MPPT is required with a control unit to reach 
the maximum power generated from the resulting PV array [5], and also as the characteristics of P-V and I-V curves are non-linear and time-varying as in Figure 1, it is necessary to implement a"maximum power point tracking MPPT" system to chase the $\mathrm{P}_{\mathrm{MPP}}$ on the $\mathrm{P}-\mathrm{V}$ curve, so that maximum power output can be gained from the PV array system [6].

Two MPPT algorithm methods are proposed in this literature; Perturb and Observe (P\&O) and Incremental Conductance (INC). For the representation of the MPPT, the PV system needs to have a DC-DC converter, the DC-DC converter can be either boost converter or buck-boost converter, they are usually used because of their efficiency high [7]. The boost converter is used in this paper to track the MPP.

The purpose of this paper is to study and compare the most suitable MPPT methods for PV applications and evaluate their performance under irradiation changes using perturb and observe method and incremental conduction method. The simulation study is designed to create an implementation of two MPPT algorithms for the PV modules connected to the load, giving a satisfying response to the problem of irradiation changes using MATLAB/Simulink program.

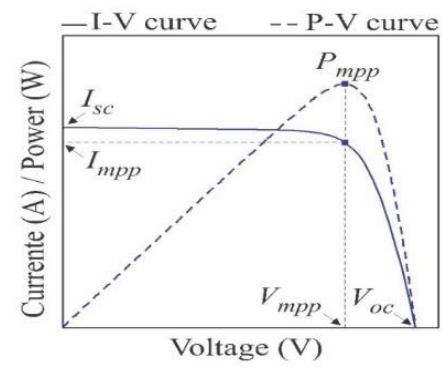

Figure 1. IV and PV characteristic curves of a solar panel

\section{NOMENCLATURE}

$\left[\boldsymbol{I}_{\boldsymbol{P V}}\right]$ PV output current in (A), $\left[\boldsymbol{V}_{\boldsymbol{P V}}\right]$ PV output voltage in (V), $\left[\boldsymbol{T}_{n}\right]$ reference temperature $=298 \mathrm{~K}$, which $=1.6$,

$[\boldsymbol{T}]$ operating temperature in Kelvins, $\left[\boldsymbol{I}_{\boldsymbol{o}}\right] \mathrm{PV}$ saturation current in (A), $[\boldsymbol{n}] \mathrm{PV}$ ideality--factor,

$\left[\boldsymbol{I}_{\boldsymbol{p h}}\right]$ PV light generated current in (A), [K] Boltzman-constant, which $=(1.3805 \times 10-23 \mathrm{~J} / \mathrm{K}),[\boldsymbol{q}]$ Charge of electron, which $=(1.6 \times 10-19 \mathrm{C}),\left[\boldsymbol{R}_{\boldsymbol{s}}\right]$ series resistance of a PV, which $=0.0111 \Omega,\left[\boldsymbol{R}_{\boldsymbol{s h}}\right]$ parallel resistance of a PV which $=1000 \Omega,\left[\boldsymbol{E}_{\boldsymbol{g o}}\right]$ the band gap of the silicon, which $=1.1 \mathrm{eV},\left[\boldsymbol{K}_{\boldsymbol{i}}\right]$ short circuit current temperature c-efficient, which $=0.0032 \mathrm{~A} / \mathrm{oC},[\boldsymbol{G}]$ the illumination of $\mathrm{PV}$ in $(\mathrm{W} / \mathrm{m} 2)$ which $=1000 \mathrm{~W} / \mathrm{m} 2,\left[\boldsymbol{I}_{\text {scr }}\right]$ short -circuit current with irradiation $(1000 \mathrm{~W} / \mathrm{m} 2)$ and temperature $25 \mathrm{oC}=2.55 \mathrm{~A},\left[\boldsymbol{N}_{\boldsymbol{s}}\right]$ Cells number in series, $\left[\boldsymbol{N}_{\boldsymbol{p}}\right]$ Cells number in parallel.

\section{PHOTOVOLTAIC MODELING}

\subsection{Model Reference}

PV module of MXS 60W is taken as a reference for the simulation as given in Table 1 [8]

Table 1. 60W PV Module Specifications

\begin{tabular}{cc}
\hline Rated Power & $60 \mathrm{~W}$ \\
\hline Voltage at Maximum power $\left(\mathrm{V}_{\mathrm{mp}}\right)$ & $17.1 \mathrm{~V}$ \\
Current at Maximum power $\left(\mathrm{I}_{\mathrm{mp}}\right)$ & $3.5 \mathrm{~A}$ \\
Open circuit voltage $\left(\mathrm{V}_{\mathrm{OC}}\right)$ & $21.1 \mathrm{~V}$ \\
Short circuit current $\left(\mathrm{I}_{\mathrm{SCr}}\right)$ & $3.8 \mathrm{~A}$ \\
Total number of cells in series $\left(\mathrm{N}_{\mathrm{s}}\right)$ & 36 \\
Total number of cells in parallel $\left(\mathrm{N}_{\mathrm{p}}\right)$ & 1 \\
\hline
\end{tabular}

\subsection{Solar Cell Module}

A solar panel can be built by connecting series cells and parallel cells to form the PV. In this paper $60 \mathrm{~W}$ PV model is used with NS $=36$ and NP $=1$. The solar cells are a p-n semiconductor junction, which can be represented as a diode circuit, as shown in Figure 2. This circuit includes photocurrent Iph, Rs and 
Rsh are the series and parallel resistance of the PV cell respectively. The PV panel can be formed mathematically as shown [9-11].

\subsubsection{Shunt Current Ish Module}

Matlab Simulation of shunt current Ish as shown in Figure 3.

$$
I_{s h}=\left(V+I R_{s}\right) / R_{s h}
$$

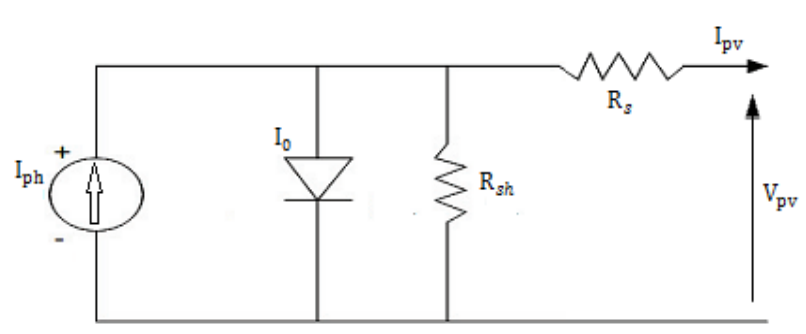

Figure 2. Solar cell circuit

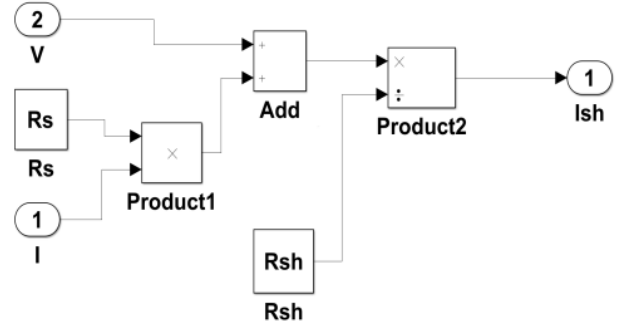

Figure 3. Matlab Simulation of shunt current Ish

\subsubsection{Temperature module from degrees to Kelvin}

Matlab simulation of temperature conversion from degrees Celsius to Kelvin as shown in Figure 4.

$$
T_{\text {kelvin }}=273+T_{\text {degree }}
$$

\subsubsection{Photo Current Iph Module}

Matlab simulation of photo current $I_{p h}$ as shown in Figure 5.

$$
I_{p h}=\left[I_{s c}+K_{i}(T-298)\right] G / 1000
$$

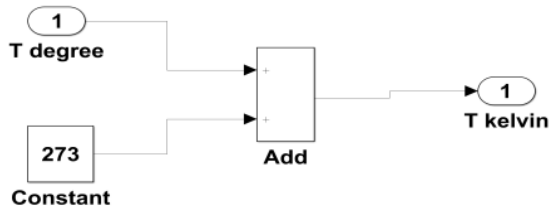

Figure 4. Matlab simulation of temperature conversion from degrees Celsius to Kelvin

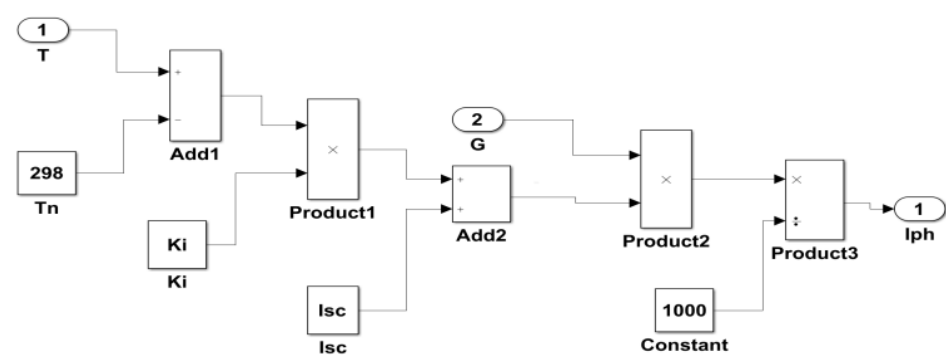

Figure 5. Matlab simulation of photo current $I_{p h}$

\subsubsection{Reverse Saturation Current Module Irs}

Simulation of the reverse saturation current $I_{r s}$ as shown in Figure 6.

$$
I_{r s}=I_{s c} /\left[\exp \left(\frac{q V_{o c}}{N_{S} k n T}\right)-1\right]
$$

\subsubsection{Saturation Current Io Module}

Matlab simulation of saturation current $I_{o}$ as shown in Figure 7.

$$
I_{o}=I_{r s}\left(T / T_{n}\right)^{3} \exp \left[q E_{g o}\left(\frac{1}{T_{n}}-\frac{1}{T}\right) / n K\right]
$$




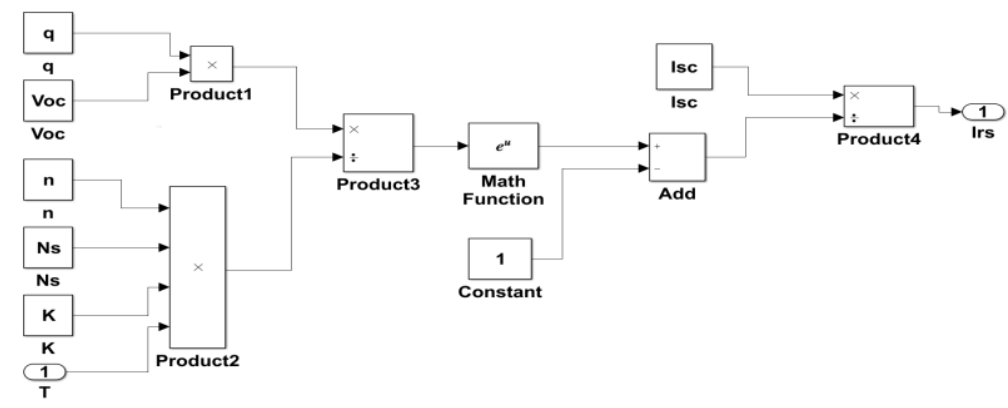

Figure 6. Simulation of the reverse saturation current $I_{r s}$

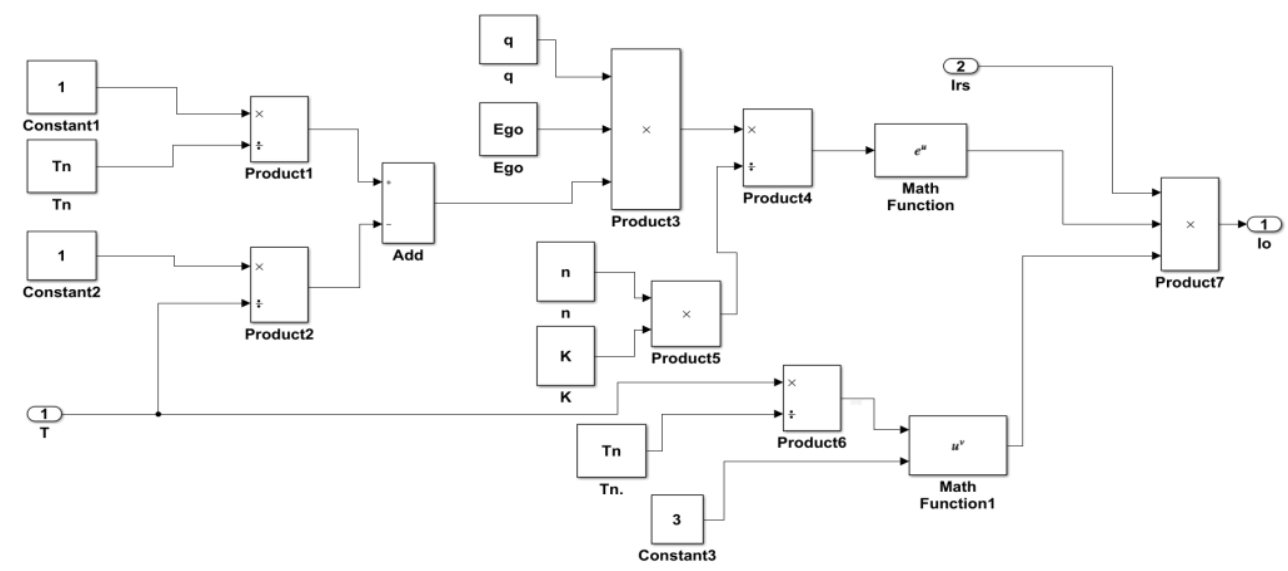

Figure 7. Matlab simulation of saturation current $I_{o}$

\subsubsection{The current output of PV module IPV}

Simulation of output current of PV module $I_{p v}$ as shown in Figure 7.

$$
I_{p v}=N_{P} \times I_{p h}-N_{P} \times I_{o}\left\{\exp \left[\frac{q\left(V+I R_{S}\right)}{K n T}\right]-1\right\}-I_{s h}
$$

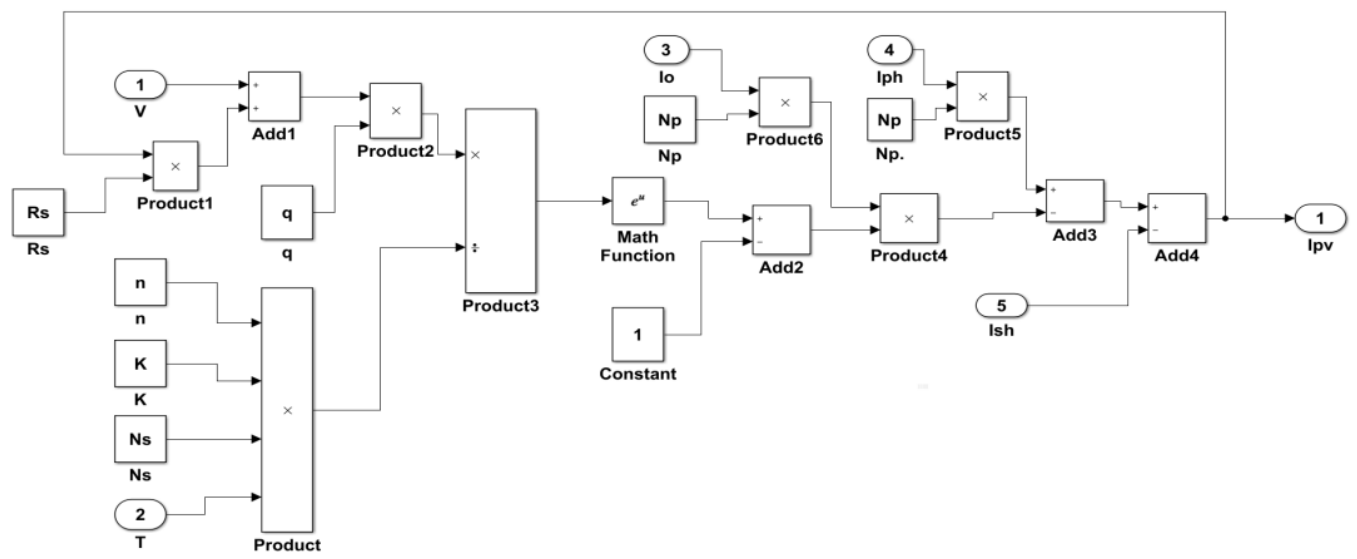

Figure 8. Simulation of output current of PV module $I_{p v}$

All six models above are connected as shown in Figure 9, and a ramp function is used to simulate the whole axis of voltage for the characteristics of I-V and P-V curves, and the slope of the ramp function is set to 10 . 


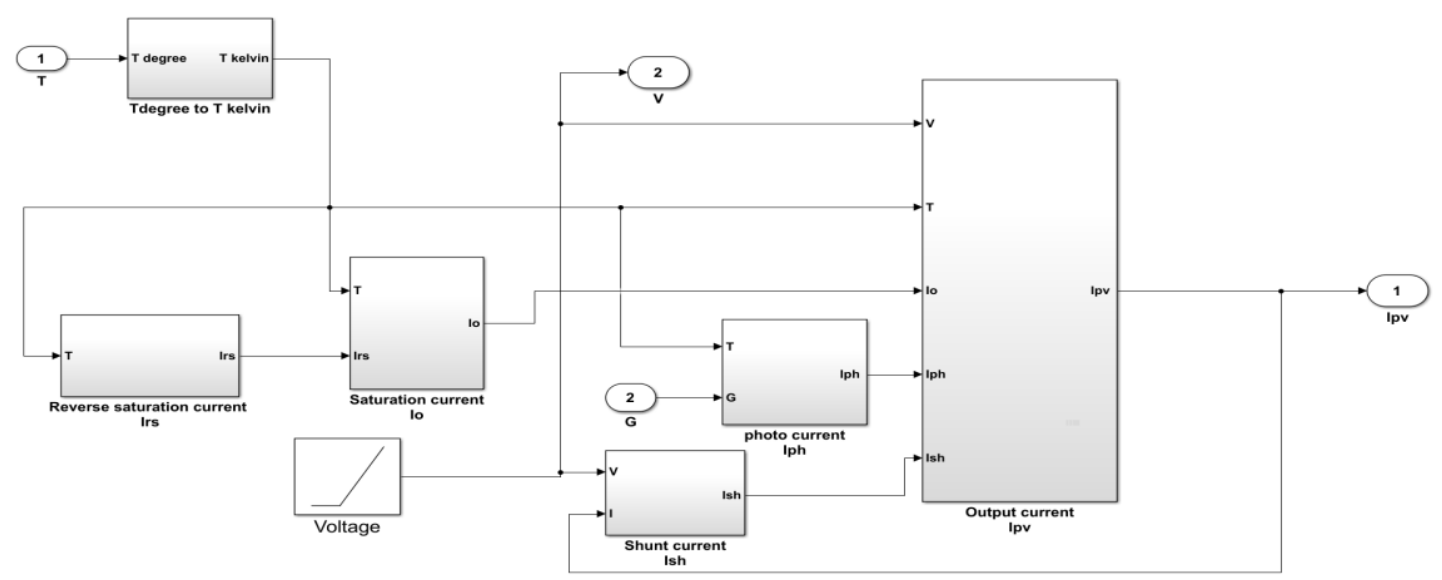

Figure 9. Simulation of all six models

\section{ALGORITHM OF MPPT CONTROL}

PV system curves are influenced by temperature and solar irradiation. Furthermore, daily irradiation behavior has abrupt variations during day time. The MPP of the PV arrays under these conditions keeps changing continuously, and the operating point of the PV cell should also change consequently to maximize the extracted energy. The MPPT technique is useful to maintain the operation point of a PV array at its maximum [12].

\subsection{DC-DC Boost Converter}

The DC-DC boost converter circuit shown in Figure 10, the circuit consists of DC input source voltage Vin to represent the PV output voltage, L is boost inductor, boost controlled switch IGBT, C2 is boost filter capacitor, boost diode $\mathrm{D}$ and $\mathrm{R}$ is load resistance [13-14].

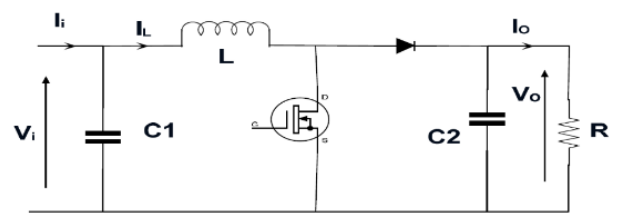

Figure 10. DC-DC converter

The boost controller switch IGBT is controlled by a duty-cycle (d) and the gain DC voltage of the DC-DC boost converter is:

$$
\frac{V_{\text {out }}}{V_{\text {in }}}=\frac{1}{1-d}
$$

Vout is the voltage output from the boost converter, Vin is the voltage input to the boost converter from the PV array and (d) is the duty-cycle generated from MPPT controller either by P\&O or INC to boost the input voltage using pulse width modulation (PWM) technique as shown in Figure 11 [15].

Details of the boost converter are given in Table 2 . These details can be determined mathematically from the designed circuit of a dc-dc boost converter [16].

Table 2. DC-DC Boost Converter Component Values

\begin{tabular}{ll}
\hline Component & Rating \\
\hline L 1 & $150[\mu \mathrm{H}]$ \\
C2 & $100[\mu \mathrm{F}]$ \\
R & $470[\mu \mathrm{F}]$ \\
& $30[\Omega]$ \\
\hline
\end{tabular}


Two methods of MPPT are taken in this paper.

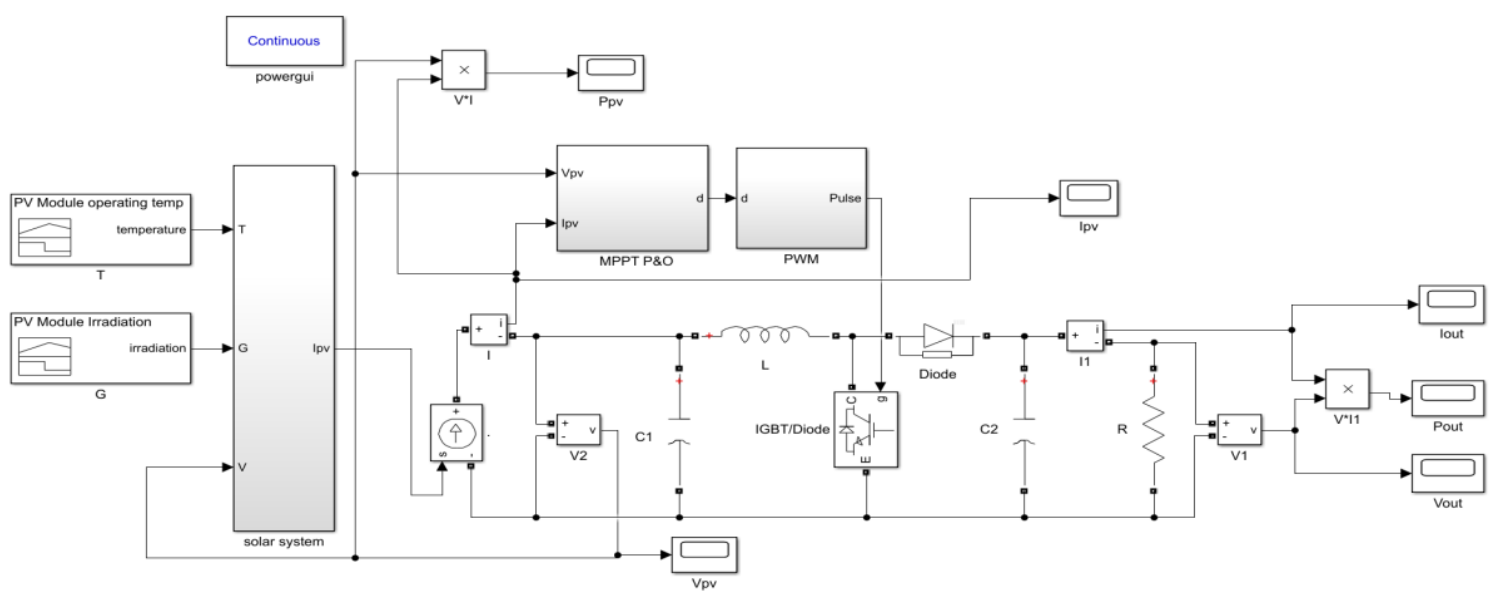

Figure 11. Configuration of PV system to control the boost converter with MPPT

\subsection{Perturb and Observe Method (P\&O)}

The algorithm based on the process of perturbation (increase or decrease) of power based on increases or decrease the voltage of the PV array's, based on the observation of the power output of the PV. The algorithm of $\mathrm{P} \& \mathrm{O}$ is continuously increasing or decreasing the voltage reference by depending on the previous value of the power sample. The $\mathrm{P} \& \mathrm{O}$ method is simpler as it requires sensors for the voltage and current only, and it is easier to be implemented [17]. In this algorithm, the time taken to reach the MPP is longer than that in INC. When the MPP point is reached, $\mathrm{P} \& \mathrm{O}$ keeps alternating around the point and would never stop on it.

According to the algorithm of $\mathrm{P} \& \mathrm{O}$, when a small increase in the operating voltage of the $\mathrm{PV}$ array is perturbed, and if the power change $\Delta \mathrm{P}$ is (positive), it is going in a direction towards MPP and it should keep on the perturbing along the same direction. If the changes in power $\Delta \mathrm{P}$ is (negative), then the operating point is moving away from the MPP point and the sign has to be changed of the delivered perturbation.

The algorithm of $\mathrm{P} \& \mathrm{O}$ is shown in Figure 12; it is based on perturbing the operating voltage periodically and comparing the previous one with it. If the difference in voltage $\Delta \mathrm{V}$ and the difference in power $\Delta \mathrm{P}$ are positive then the $\mathrm{PV}$ array voltage is increased. If both $\Delta \mathrm{P}$ and $\Delta \mathrm{V}$ are negative then there is also an increase in the PV array voltage, otherwise, the voltage is decreased. Similarly, the next period is reiterated until the point of maximum power is reached [18-19].

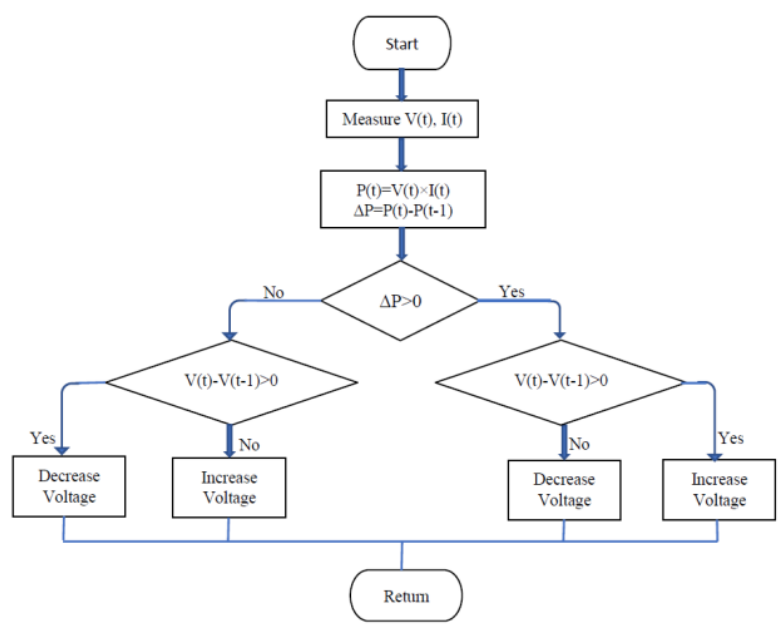

(a). Flowchart of $\mathrm{P} \& \mathrm{O}$

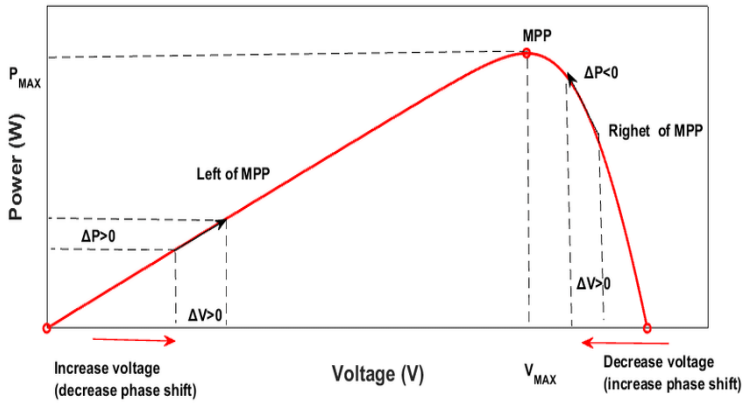

(b). P-V graph

Figure 12. P\&O control technique 
The simulink model of the MPPT P\&O algorithm shown in Figure 11 includes the 60W PV array and contains the equations required for its modeling. The DC voltage source of the boost converter is replaced by a MATLAB subsystem integrated with the PV array. Perturbing the duty ratio of the dc-dc boost converter will perturb the current of the PV array and consequently perturbs the voltage of the PV array. To calculate the power at different duty cycles and to compare it with the current operating point power, the MPPT subsystem is used. The duty cycle either decreases or increases or remains the same.

Figure 13 shows the configuration of the MPPT algorithm in MATLAB/Simulink according to the flowchart of the P\&O method expounded in Figure 12 [20].

Figure 14 shows the configuration of PWM to increase or decrease the duty-cycle used to control the boost switching IGBT, with pulse generator period 1/5000 and pulse width 50 [20].

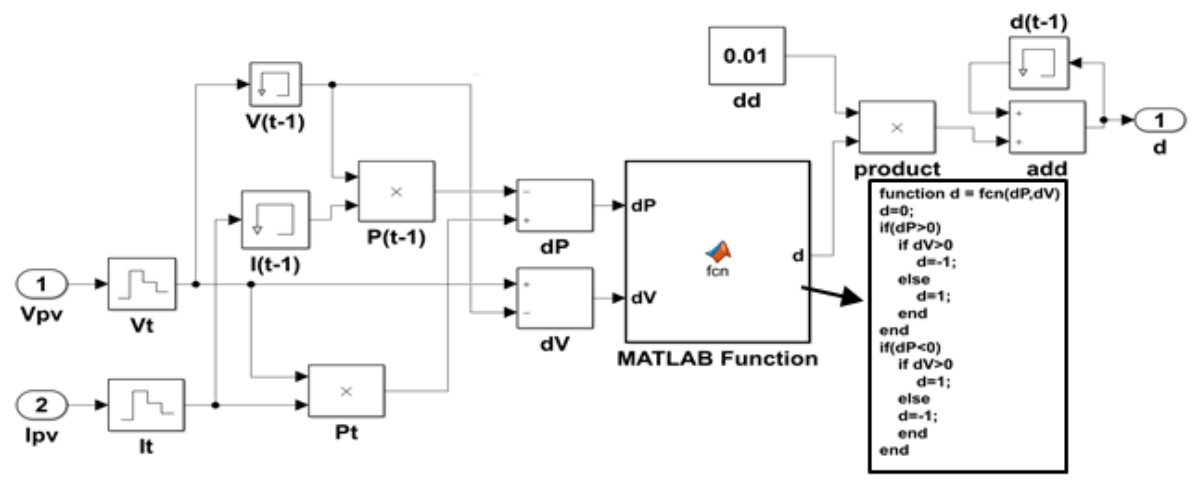

Figure 13. Configurations of $(\mathrm{P} \& \mathrm{O}) \mathrm{MPPT}$ algorithm in Simulink

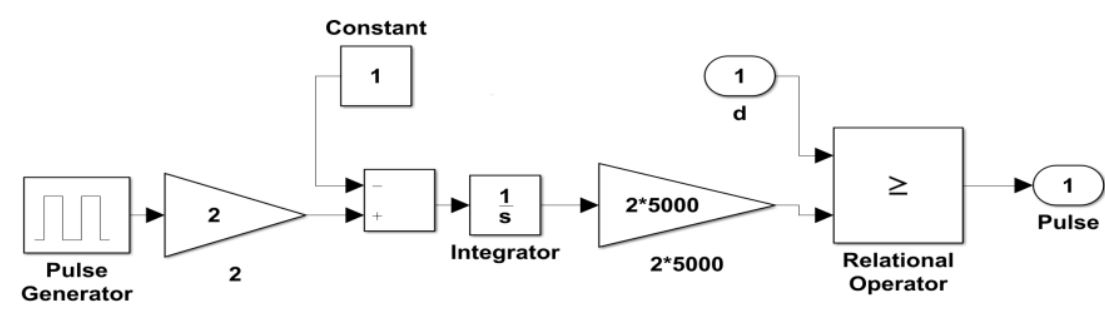

Figure 14. Configuration of PWM

\subsection{Incremental Conductance (INC)}

INC is another method for tracking the MPP. This method is used to counter the weakness of the $\mathrm{P} \& \mathrm{O}$ method [21]. The P\&O method is not capable to compare the actual operating voltage at a maximum power point with the terminal voltage of the (PV) array. The INC method is easier to implement, it has a higher tracking speed, and better efficiency, this makes INC algorithm better than P\&O [22]. The algorithm of INC is derived by differentiating the power of the PV with respect to its voltage, then the result is set equal to zero as in (8) and (9) [23-24].

At point of MPP

$\frac{d P}{d V}=\frac{d(V I)}{d V}=V \frac{d I}{d V}+I=0$

Rearranging as shown in (8),

$\frac{d I}{d V}=-\frac{I}{V}$ 
From (9), the (left-hand side) is the incremental conductance, while the (right-hand side) is the opposite instantaneous conductance. When the operating point reaches the MPP, both sides of (9) are opposite in the sign but equal in magnitude.

When an operating point is away from the MPP, two possibilities exist, either the operating point is at the (left-hand side) of MPP when incremental conductance is greater than instantaneous conductance, or at the (right-hand side) of MPP when incremental conductance is less than instantaneous conductance as shown in (10), (11), (12). The Simulink model of the InC algorithm is the same as the P\&O condition, but only different in MPPT algorithms.

$$
\begin{aligned}
& \frac{d I}{d V}=-\frac{I}{V}, \text { and } \frac{d P}{d V}=0 \text { at } M P P \\
& \frac{d I}{d V}>-\frac{I}{V}, \text { and } \frac{d P}{d V}>0 \text { left side of } M P \\
& \frac{d I}{d V}<-\frac{I}{V} \text {, and } \frac{d P}{d V}<0 \text { right side of } M P P
\end{aligned}
$$

The operation of the incremental conductance idea is shown in Figure 15.

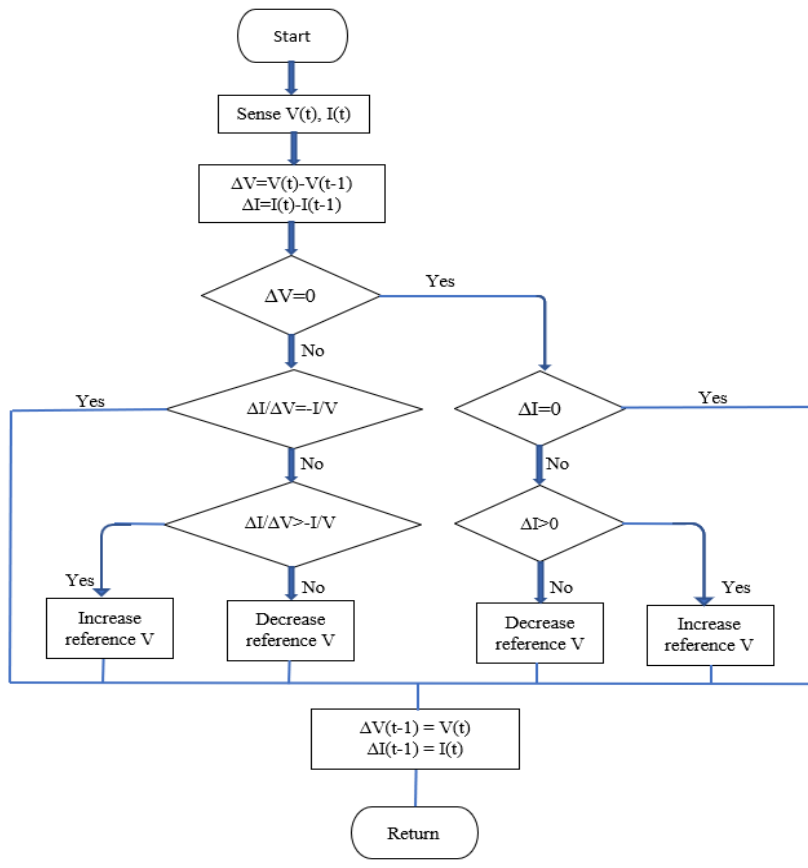

(a). Flow chart of INC

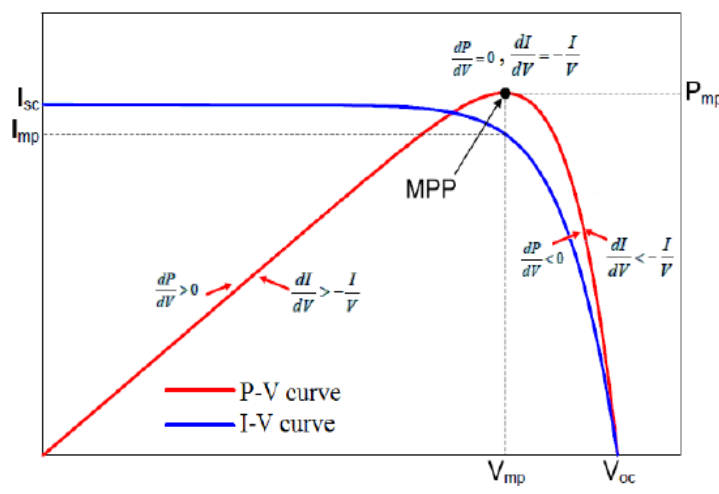

(b). P-V graph

Figure 15. Incremental conductance control technique

\section{SIMULATION RESULTS}

\subsection{Simulation Results of The PV Array Without DC-DC Converter}

In Figure 16 (a), the input irradiation until time $1 \mathrm{sec}$, is set to $1000 \mathrm{~W} / \mathrm{m} 2,1 \& 2 \mathrm{sec}$ is set to $800 \mathrm{~W} / \mathrm{m} 2,2 \& 3 \mathrm{sec}$ it is set to $600 \mathrm{~W} / \mathrm{m} 2,3 \& 4 \mathrm{sec}$ the setting is $400 \mathrm{~W} / \mathrm{m} 2$, and between $4 \& 5 \mathrm{sec}$, it is set to is $200 \mathrm{~W} / \mathrm{m} 2$. With input temperature set at $250 \mathrm{C}$ during the whole simulation.

In Figure 16 (b), the input temperature from 0 to $1 \mathrm{sec}$ is $250 \mathrm{C}$, between $1 \& 2 \mathrm{sec}$ it is $500 \mathrm{C}, 2 \& 3 \mathrm{~s}$ it is set to $750 \mathrm{C}$. With input irradiation set at $1000 \mathrm{~W} / \mathrm{m} 2$ during the whole simulation.

Figure 17 shows that the current output from the PV is decreasing, and the voltage output is also decreasing when the irradiation decreases. This would result in a net decrease in output power with a decrease in irradiation when the temperatures are constant.

In Figure 18 when the operating temperature increases, the voltage output from the PV decreases drastically, but the current output increases marginally. This results in a net reduction in the power output with a rise in temperatures. 


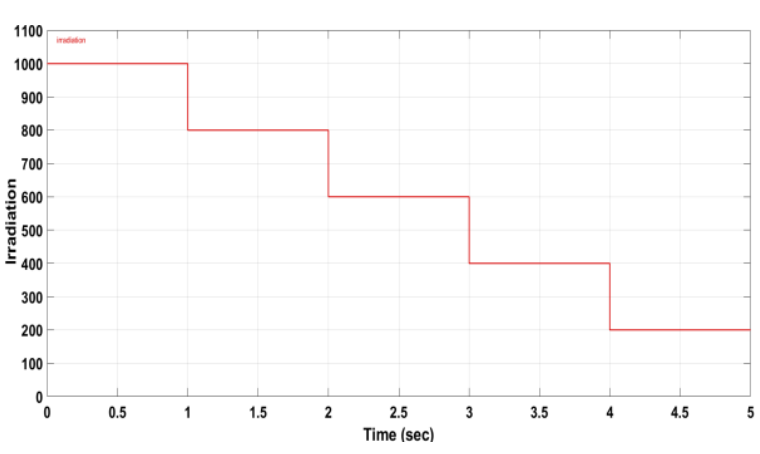

(a). Input-Time varying irradiation

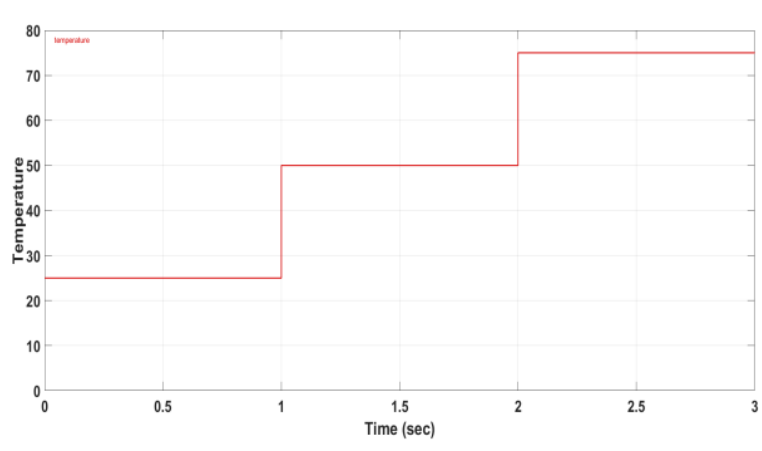

(b). Input-time varying temperature

Figure 16. Input-Time varying irradiation and temperature

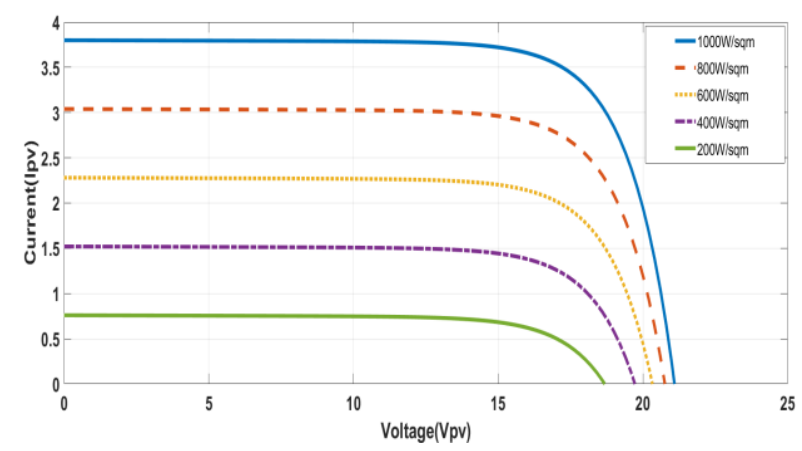

(a). Output I-V

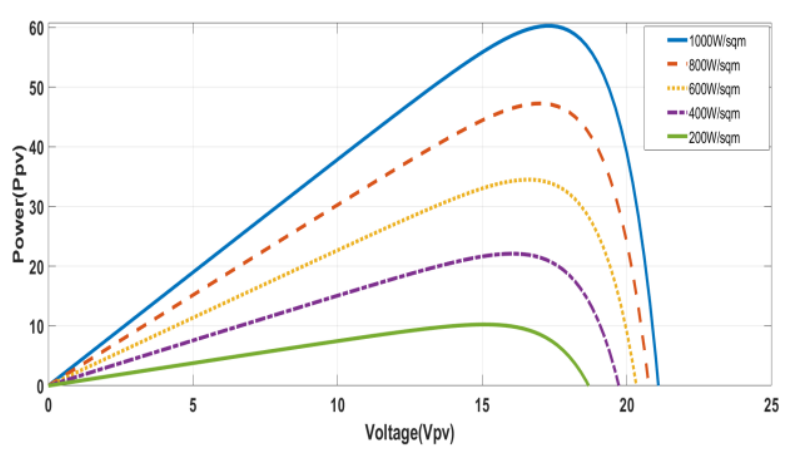

(b). Output P-V

Figure 17. Output characteristic of the PV while varying irradiation

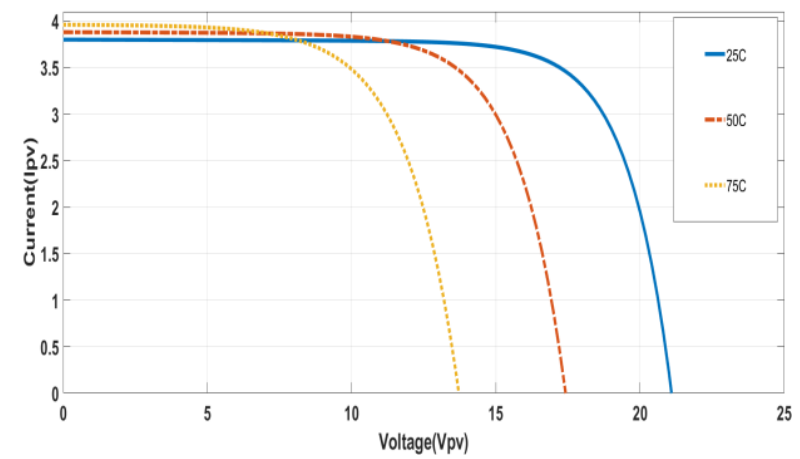

(a). Output I-V

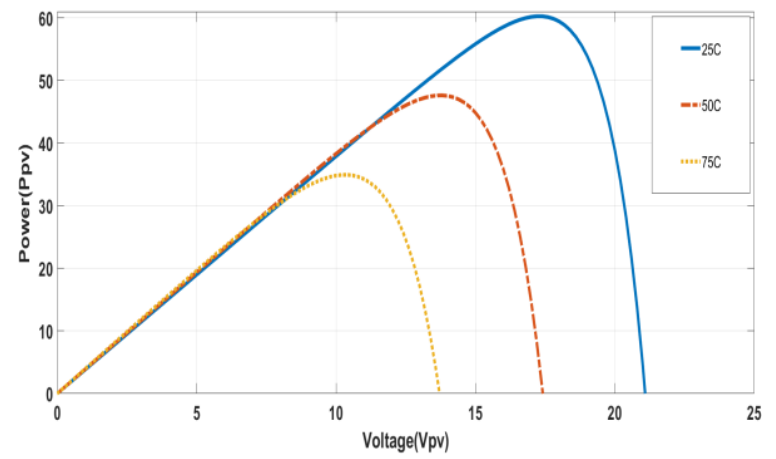

(b). Output P-V

Figure 18. Output characteristic of the PV with temperature varying

\subsection{Simulation Results of The PV Array with Resistive Load}

The irradiation is set to $1000 \mathrm{~W} / \mathrm{m} 2$ and the temperature is set to $250 \mathrm{C}$, it is seen in Figure 19 that the output DC power is about $14.41 \mathrm{~W}$ which is equal to:

$$
P=V I
$$




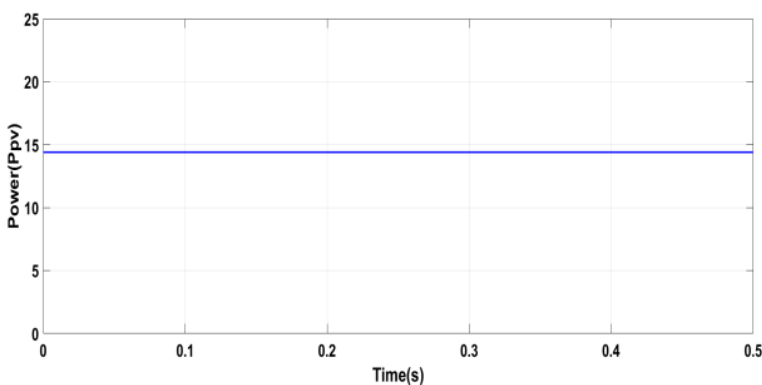

(a). Power (Ppv)

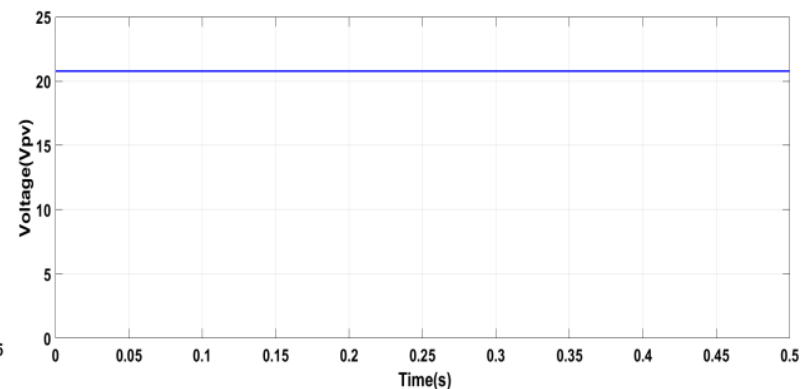

(b). Voltage (Vpv)

Figure 19. Output of the PV array with resistive load

\subsection{Simulation Results with DC-DC Boost Converter Using MPPT (P\&O, INC)}

As seen in Figure 20, the output power from the P\&O method is $56.81 \mathrm{~W}$ and the output voltage is $41.29 \mathrm{~V}$ which represents the maximum power (Pmax) and (Vmax) that can be drawn from the PV module and the maximum power was achieved in about $0.09 \mathrm{sec}$, the final value of output power has a ripple of about 1.56 as seen in Figure 20 (a).

While in the INC method the maximum power output (Pmax) of value $58 \mathrm{~W}$ is achieved with a rise time of about $0.65 \mathrm{sec}$, with a ripple of about 1.31 as seen in Figure 21 (a).

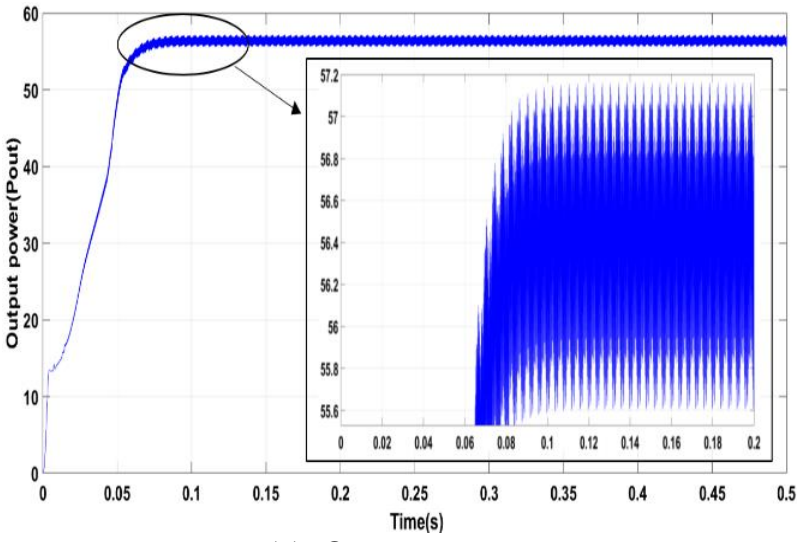

(a). Output power

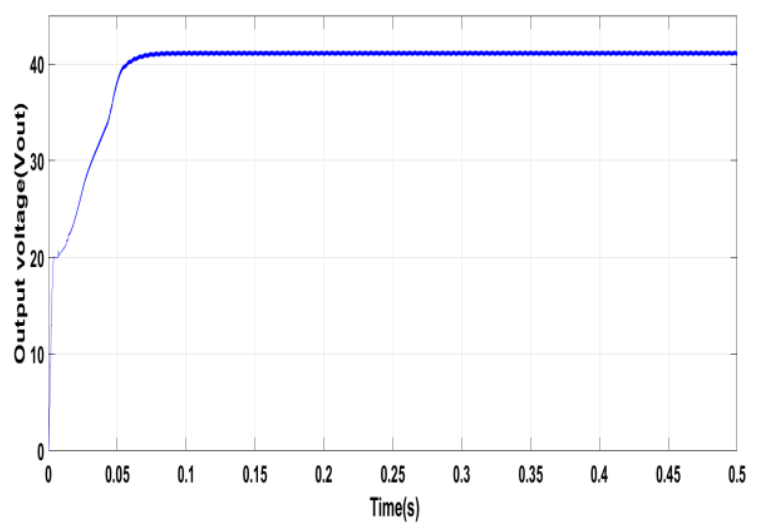

(b). Output voltage

Figure 20. The output power and voltage of the DC-DC boost converter with P\&O method

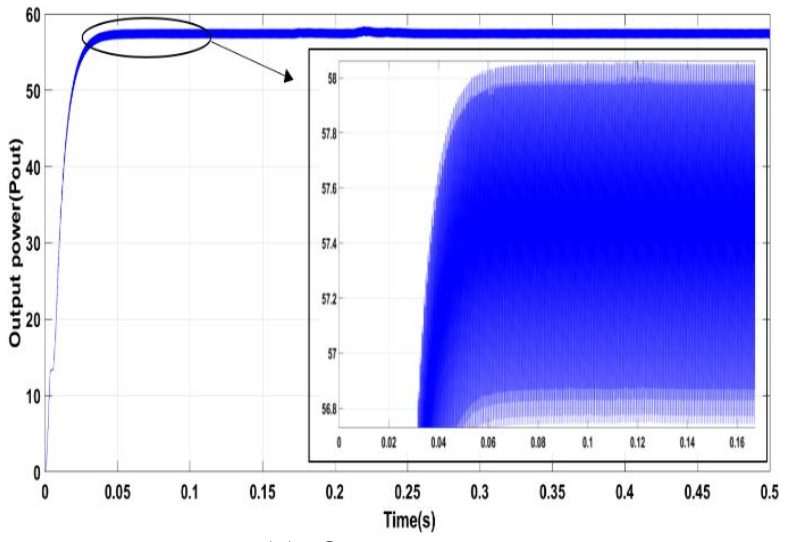

(a). Output power

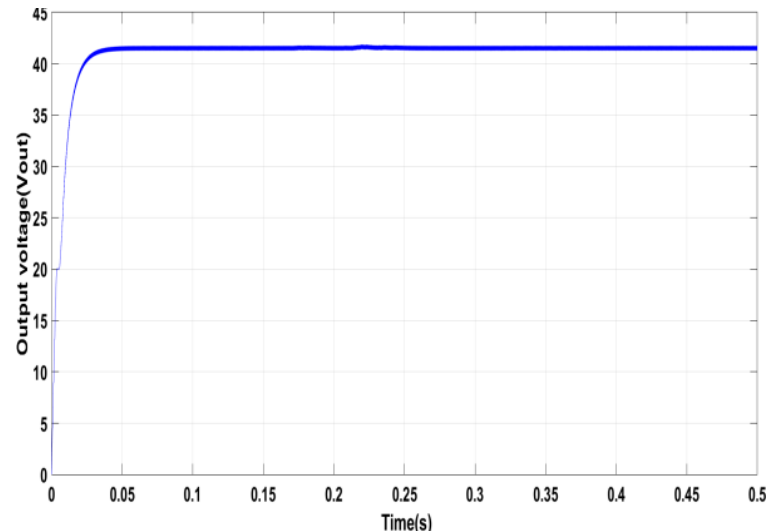

(b). Output voltage

Figure 21. The output voltage of the dc-dc boost converter with INC method 
It can be noted that after applying the MPPT algorithm the operating point at maximum power is reached at lesser rise time with INC. The result of the simulation show that the energy production from solar panels being independent and maximized of weather conditions.

\subsection{The Comparison Between $P \& O$ and InC MPPT Algorithms}

MPPT P\&O and InC algorithms are simulated and compared under the same conditions. When weather conditions are steady or change slowly, P\&O MPPT oscillates near the MPP but InC MPPT accurately finds the MPP at changing weather conditions as well. There is a comparison between these two algorithms for the different parameters are given in Table 3. The output current can be determined by (14). The results obtained in this paper from 60-watt solar panels can be compared to the results obtained from 60watt and 70-watt solar panels in [25-26].

\begin{tabular}{cccccc}
$I_{\text {out }}=\frac{P_{\text {out }}}{V_{\text {out }}}$ & \multicolumn{7}{c}{} \\
\multicolumn{7}{c}{ Table } & 3. Comparison between the MPPT P\&O and InC Algorithms & \\
\hline PV & Output Power & Output Voltage & Output Current & Time Response & Accuracy \\
\hline Without MPPT & $14.41 \mathrm{~W}$ & $20.77 \mathrm{~V}$ & $0.693 \mathrm{~A}$ & $0.0 \mathrm{sec}$ & Less \\
With MPPT P\&O & $56.81 \mathrm{~W}$ & $41.29 \mathrm{~V}$ & $1.375 \mathrm{~A}$ & $0.09 \mathrm{sec}$ & Less \\
With MPPT InC & $58 \mathrm{~W}$ & $41.72 \mathrm{~V}$ & $1.4 \mathrm{~A}$ & $0.065 \mathrm{sec}$ & Accurate \\
\hline
\end{tabular}

\section{CONCLUSIONS}

In this paper, a procedure for the mathematical modeling of the PV module is demonstrated to earn more understanding of the characteristics of P-V and I-V curves of PV module. The MPPT algorithms of $\mathrm{P} \& \mathrm{O}$ and INC are discussed and simulated by MATLAB/Simulink. The simulated MPPT controller achieved and maintained the MPP efficiently at different temperatures and irradiation levels. The simulation proved that the INC method has a higher speed, better performance with more accuracy in tracking the MPP than (P\&O) method. These two methods improve the steady-state and dynamic performances of a photovoltaic system and improve the efficiency of the dc-dc boost converter system.

\section{REFERENCES}

[1] N. Pandiarajan and R. Muthu, "Mathematical modeling of photovoltaic module with Simulink," in 2011 1st International Conference on Electrical Energy Systems, 2011, pp. 258-263.

[2] A. P. Yoganandini and G. S. Anitha, "A cost effective computational design of maximum power point tracking for photo-voltaic cell," Int. J. Electr. Comput. Eng., vol. 9, no. 2, p. 851, 2019.

[3] A. S. Samosir, H. Gusmedi, S. Purwiyanti, and E. Komalasari, "Modeling and Simulation of Fuzzy Logic based Maximum Power Point Tracking (MPPT) for PV Application.," Int. J. Electr. Comput. Eng., vol. 8, no. 3, 2018.

[4] H. Attia, "Fuzzy Logic Controller Effectiveness Evaluation through Comparative Memberships for Photo voltaic Maximum Power Point Tracking Function," Int. J. Power Electron. Drive Syst., vol. 9, no. 3, p. 1147, 2018.

[5] A. A. Abdulrazzaq and A. H. Ali, "Efficiency Performances of Two MPPT Algorithms for PV System With Different Solar Panels Irradiancess," Int. J. Power Electron. Drive Syst., vol. 9, no. 4, p. 1755, 2018.

[6] M. A. Eltawil and Z. Zhao, "MPPT techniques for photovoltaic applications," Renew. Sustain. energy Rev., vol. 25, pp. 793-813, 2013.

[7] R. Palanisamy, K. Vijayakumar, V. Venkatachalam, R. M. Narayanan, D. Saravanakumar, and K. Saravanan, "Simulation of various DC-DC converters for photovoltaic system," Int. J. Electr. Comput. Eng., vol. 9, no. 2, pp. 917, 2019.

[8] Www.solarelectricsupply.com/media/custom/upload/Solarex-MSX64.pdf

[9] S. Chowdhury, S. P. Chowdhury, G. A. Taylor, and Y. H. Song, "Mathematical modelling and performance evaluation of a stand-alone polycrystalline PV plant with MPPT facility," in 2008 IEEE Power and Energy Society General Meeting-Conversion and Delivery of Electrical Energy in the 21st Century, 2008, pp. 1-7.

[10] J.-H. Jung and S. Ahmed, "Model construction of single crystalline photovoltaic panels for real-time simulation," in 2010 IEEE Energy Conversion Congress and Exposition, 2010, pp. 342-349.

[11] S. Nema, R. K. Nema, and G. Agnihotri, "MATLAB/Simulink based study of photovoltaic cells/modules/array and their experimental verification," Int. J. Energy Environ., vol. 1, no. 3, pp. 487-500, 2010.

[12] I. H. Altas and A. M. Sharaf, "A novel on-line MPP search algorithm for PV arrays," IEEE Trans. Energy Convers., vol. 11, no. 4, pp. 748-754, 1996.

[13] Rashid, M. H. (2017). :"Power electronics handbook". Butterworth-Heinemann.

[14] N. Hashim, Z. Salam, D. Johari, and N. F. N. Ismail, "DC-DC Boost Converter Design for Fast and Accurate MPPT Algorithms in Stand-Alone Photovoltaic System," Int. J. Power Electron. Drive Syst., vol. 9, no. 3, pp. 1038, 2018. 
[15] J. J. Nedumgatt, K. B. Jayakrishnan, S. Umashankar, D. Vijayakumar, and D. P. Kothari, "Perturb and observe MPPT algorithm for solar PV systems-modeling and simulation,” in 2011 Annual IEEE India Conference, 2011, pp. 1-6.

[16] G. Ofualagba, I. K. Charles, and O. A. Okiemute, "Optimizing the output current for a DC-DC converter," Control Theory Informatics, vol. 2, no. 2, pp. 49-61, 2012.

[17] P. Lei, Y. Li, and J. E. Seem, "Sequential ESC-based global MPPT control for photovoltaic array with variable shading," IEEE Trans. Sustain. Energy, vol. 2, no. 3, pp. 348-358, 2011.

[18] A. S. Hiwale, M. V Patil, and H. Vinchurkar, "An efficient MPPT solar charge controller," Int. J. Adv. Res. Electr. Electron. Instrum. Eng., vol. 3, no. 7, 2014.

[19] M. L. Azad, S. Das, P. K. Sadhu, B. Satpati, A. Gupta, and P. Arvind, "P\&O algorithm based MPPT technique for solar PV system under different weather conditions," in 2017 International Conference on Circuit, Power and Computing Technologies (ICCPCT), 2017, pp. 1-5.

[20] A. Joseph and J. Kamala, "PV array characteristics analysis under partial shading \& modeling of P\&O MPPT applied boost convertor using Matlab/Simulink," in 2013 International Conference on Energy Efficient Technologies for Sustainability, 2013, pp. 596-601.

[21] K. H. Hussein, I. Muta, T. Hoshino, and M. Osakada, "Maximum photovoltaic power tracking: an algorithm for rapidly changing atmospheric conditions," IEE Proceedings-Generation, Transm. Distrib., vol. 142, no. 1, pp. 59-64, 1995.

[22] H. N. Zainudin and S. Mekhilef, "Comparison study of maximum power point tracker techniques for PV systems," 2010.

[23] K. Kobayashi, I. Takano, and Y. Sawada, "A study of a two-stage maximum power point tracking control of a photovoltaic system under partially shaded insolation conditions," Electr. Eng. Japan, vol. 153, no. 4, pp. 39-49, 2005.

[24] M. L. Azad et al., "An efficient Mppt approach of PV systems: incremental conduction pathway," Indones. J. Electr. Eng. Comput. Sci., vol. 15, no. 3, pp. 1189-1196, 2019.

[25] V. K. Viswambaran, A. Ghani, and E. Zhou, "Modelling and simulation of maximum power point tracking algorithms \& review of MPPT techniques for PV applications," in 2016 5th International Conference on Electronic Devices, Systems and Applications (ICEDSA), 2016, pp. 1-4.

[26] I. W. Christopher and R. Ramesh, "Comparative study of P\&O and InC MPPT algorithms," Am. J. Eng. Res., vol. 2, no. 12, pp. 402-408, 2013.

\section{BIOGRAPHIES OF AUTHORS}

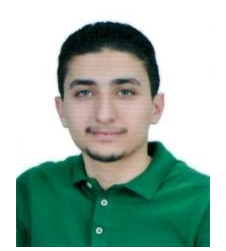

Hayder Moayad Abd AlHussain was born in Baghdad, Iraq, on March 15, 1994. He received his Bachelor's degree in electrical engineering in 2016 from Electrical Power Engineering Techniques Department, Al-Mamoun University College, Baghdad, Iraq. His current research works include the development \& Improve the efficiency of renewable energy systems, control techniques, and artificial intelligence.

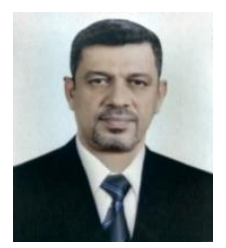

Dr. Naseer M. Yasin was born in Messan city, iraq, on May 20, 1965. He was an Assistant Professor of Electrical Engineering, at the Electrical Engineering Technical College, Middle Technical University - Iraq, in 2019. He received the PhD. degree from College of Engineering, University of Basrah, in 2014. He received the MASTER degree in Electrical Engineering from Electrical Engineering Technical College, Middle Technical University, in 2007. His research interests include electrical motor drives, renewable energy and artificial intelligence. 